\title{
PENGGUNAAN MEDIA TIGA DIMENSI DALAM MENINGKATKAN HASIL BELAJAR ATEMATIKA SISWA KELAS V MIN 2 LOMBOK BARAT TAHUN PELAJARAN 2017/2018
}

\author{
Mappanyompa \\ 1,2Program Studi Komunikasi Penyiaran Islam, Universitas Muhammadiyah Mataram, Indonesia \\ Myompakaltim@gmail.com
}

\begin{tabular}{l} 
INFO ARTIKEL \\
\hline Riwayat Artikel: \\
Diterima: 09-09-2019 \\
Disetujui: 30-10-2019
\end{tabular}

\section{Kata Kunci:}

Hasil Belajar;

Bangun Ruang;

Media tiga dimensi.

\section{Keywords:}

Learning outcomes;

Build space;

Three-dimensional

Media.

\section{A. LATAR BELAKANG}

Pendidikan sebagai salah satu sektor yang paling penting dalam pembangunan nasional, dijadikan andalan utama untuk berfungsi semaksimal mungkin dalam upaya meningkatkan kualitas hidup manusia Indonesia, dimana iman dan takwa kepada Tuhan Yang Maha Esa menjadi sumber motivasi kehidupan segala bidang.

\section{ABSTRAK}

Abstrak: Dalam penelitian ini masalah yang ingin dijawab adalah bagaimana penggunaan media bangun ruang tiga dimensi dapat meningkatkan hasil belajar siswa kelas V MIN 2 Lombok Barat tahun pelajaran 2017/2018. Jenis penelitian ini menggunakan tindakan kelas. Dengan model sikus yang berulang dan berkelanjutan. Penelitian tindakan kelas ini dilakukan dengan II siklus. Tiap siklusnya merupakan rangkaian kegiatan yang terdiri dari 1) Perencanaan, 2) Pelaksanaan tindakan, 3) Observasi, dan 4) Refleksi. Sabjek dalam penelitian ini adalah siswa kelas V MIN 2 Lombok Barat yang berjumlah 24 orang. Objek dalam penelitian ini adalah hasil belajar materi bangun ruang. Instrumen yang digunakan berupa soal tes, lembar observasi dan dokumentasi. Data yang diperoleh dianalisis secara deskriptif kuantitatif. Hasil dari penelitian ini menunjukan bahwa pengguanaan media bangun ruang tiga dimensi pada mata pelajaran Matematika mampu peningkatan hasil belajar siswa. Hal inidapat dilihat dari meningkatnya nilai siswa materi bangun ruang sebelum dan sesudah diberi tindakan. Dilihat dari rata-rata nilainya dari prasiklus sebesar 59,3, Siklus I sebesar 69,3 dan siklus II sebesat 77,5 dengan presentase ketuntasan pada prasiklus menccapai $41,6 \%$, silus I mencapai $66,6 \%$, dan Siklus II mencapai $91,6 \%$.

Abstract: In this research issue that wants to be answered is how the use of media to build three-dimensional space can improve student learning outcomes V MIN 2 class West Lombok year lesson 2017/2018. This type of research uses class actions. With repeated and continuous sicus models. This class action research is done with the II cycle. Each cycle is a series of activities consisting of 1) planning, 2) Implementation of action, 3) observation, and 4) reflection. Sabjek in this study is a student at V MIN 2 West Lombok, a total of 24 people. The object in this study is the outcome of learning spatial building material. The instruments used are test questions, observation sheets and documentation. The obtained Data is analyzed in a quantitative descriptive. The results of this study showed that the media successfully to build three-dimensional space on the subject of mathematics is able to increase student learning outcomes. This can be seen from the increasing grades of material students waking up space before and after being given action. Judging from the average of the value of the Prasiklus 59.3, cycle I of 69.3 and cycle II at the 77.5 with a percentage of the submission of the prasiklus reached $41.6 \%$, Silus I reached $66.6 \%$, and cycle II reaches $91.6 \%$.
Sesuai dengan definisi pendidikan yang tercantum dalam Undang-undang Republik Indonesia nomor 20 Tahun 2003 tentang sistem Pendidikan Nasional Bab I pasal 1 "Pendidikan adalah usaha sadar dan terencana untuk mewujudkan suasana belajar dan proses pembelajaran agar peserta didik secara aktif mengembangkan potensi dirinya untuk memiliki kekuatan spiritual keagamaan, pengendalian diri, 
kepribadian, kecerdasan, akhlak mulia, serta keterampilan yang diperlukan dirinya, masyarakat, bangsa dan negara." 1

Matematika sebagai salah satu bidang studi yang memegang peranan penting dalam pencapaian tujuan pendidikan secara umum, Karena Matematika merupakan sarana berpikir logis, analisis, dan sistematis sehingga dapat menunjuang materi pembelajaran lainnya. semestinya sejak dini dilatih untuk mengetahui dan menyukai Matematika. Namun pada kenyataannya, sedikit siswa yang kurang berminat terhadap bidang studi Matematika. Dalam benak mereka Matematika adalah mata pelajaran yang sulit dan membosankan. Hal ini berdampak pada rendahnya hasil belajar Matematika hampir pada semua jenjang pendidikan.

Kesulitan belajar Matematika bukan sematamata karena materi pelajaran Matematika, tetapi disebabkan kemampuan guru dalam mengelola pembelajaran Matematika yang kurang efektif. Untuk mengahadapi tuntutan tersebut, perlu dikembangkan pembelajaran Metematika yang tidak variatif

Media pembelajaran adalah bahan, alat, atau teknik yang digunakan dalam kegiatan belajar mengajar dengan maksud agar proses interaksi komunikasi edukasi antara guru dan siswa dapat berlangsung secara tepat guna dan berdaya guna.

Pentingnya media dalam proses pembelajaran adalah proses, karena proses inilah yang menentukan tujuan pembelajaran akan tercapai atau tidak tercapai. Ketercapaian dalam proses belajar mengajar ditandai dengan adanya perubahan tingkah laku. Perubahan tingkah anku tersebut baik yang menyangkut perubahan bersifat penegtahuan (kognitif), keterampilan (psikomotor) maupun yang menyangkut nilai dan sikap (afektif). ${ }^{2}$

Siswa Madrasah Ibtidaiyah umurnya berkisar anatara 6 atau 7 tahun, sampai 12 atau 13 tahun. Menurut peaget, mereka berada pada fase operasional kongkret. Kemampuan yang tampak pada fase ini adalah kemampuan dalam proses berpikir untuk mengoperasikan kaidah-kaidah logika, meskipun masih terkait dengan objek yang bersifat konkret.

.Berdasarkan hasil observasi dan dokumentasi awal yang diperoleh dari beberapa informasi kecendrungan siswa kelas V MIN 2 Lombok Barat terlihat bahwa: 1) kemampuan siswa dalam

${ }^{1}$ Undang Undang Republik Indonesia NO 20 Tahun 2003 tentang Sistem Pendidikan Nasional

2 Pentingnya media dalam pembelajaran. http://belajarpsikologi.com/pentingnya-media-dalam-pembelajaran/ (di unduh pada tanggal 25 februari 2018) memahami sifat-sifat bangun dan hubungan antar bangun masih rendah, 2) siswa belum memahami dengan baik hubungan antara konsep yang satu dengan konsep yang lain, 3) penggunaan metode pembelajaran masih bersifat konvensional yaitu metode-metode lama yang tetap digunakan seperti ceramah, latihan, dan penugasan, 4) ketuntasan siswa masih di bawah rata-rata ketuntasan klasikal hanya 70\% tuntas secara klasikal, terlihat dari 24 siswa yang berprestasi hanya 5 orang, ini dibuktikan dengan nilai rata-rata yang diperoleh siswa 55,0 dengan persentase ketuntasan 20,83\% sedangkan 19 siswa masih tergolong rendah. Angka tersebut masih tergolong sangat rendah karena belum mencapai standar yang telah ditentukan. $^{3}$

\section{B. METODE PENELITIAN}

Adapun jenis penelitian yang digunakan adalah penelitian tindankan kelas (PTK). Penelitian tindakan kelas adalah penelitian yang dilakukan oleh guru atau peneliti di dalam kelas, dengan tujuan untuk memperbaiki dan meningkatkan proses dan praktik pembelajaran. 4 Metode penelitian tindakan kelas ini menerangkan pada suatu kajian yang benar-benar dari situasi alamiah kelas. Tempat dam waktu Penelitian; Penelitian ini dilaksanakan di kelas V MIN 2 Lombok Barat Desa Sesela kecamatan Gunung Sari Kabupaten Lombok Barat. Lokasi dipilih berdasarkan masalah yang ditemukan peneliti ketika observasi awal. Peneliti menemukan bahwa penggunaan metode pembelajaran masih bersifat konvensional yaitu metode-metode lama yang tetap digunakan seperti ceramah, latihan, dan penugasan, dan ketuntasan siswa masih di bawah rata-rata ketuntasan klasikal hanya $70 \%$.

Adapun rancangan yang dimaksud adalah tindakan berupa peningkatan hasil belajar Matematika siswa dengan penggunaan media tiga dimensi pada siswa kelas V MIN 2 Lombok Barat tahun pelajaran 2017/2018 dengan materi yang dilakukan penelitian adalah mengidentifikasi sifatsifat bangun ruang. Dalam rancangan penelitian tindakan kelas ini akan dilaksanakan dalam beberapa siklus. Pelaksanaan dari masing-masing siklus terdiri dari perencanaan, pelaksanaan tindakan, observasi dan refleksi seperti tertera pada gambar dibawah ini.

Setiap siklus dalam penelitian tindakan kelas terdiri (4) empat tahap yaitu perencanaan,

3 Observasi dan Dokumentasi MIN 2 Lombok Barat, Tanggal 19 Maret 2018

${ }^{4}$ Kunandar, Penelitian Tindakan Kelas, Sebagai Pengembangan Profesi Guru, (Jakarta: RajaGrafindo Persada, 2008), 44-45 
pelaksanaan tindakan, observasi dan refleksi. Secara rinci perencanaan tindakan untuk setiap siklus dapat dijabar sebagai berikut:

1) Silkus pertama: a). Perencanaan Tindakan: 1). Peneliti mensosalisasikan penggunaan media tiga dimensi pada guru bidang studi Matamatika, 2). Penyusunan perencanaan pembelajaran, 3).Membuat lembar observasi, 3). Menyusun LKS (Lembar Kerja Siswa), 4). Soal tes. b). Pelaksanaan tindakan: Dalam tahap pelaksanaan tindakan yang dilakukan oleh peneliti adalah melaksanakan semua hal yang telah direncanakan pada tahap perencanaan sesuai dengan rencana pelaksanaan pembelajaran pada pokok pembahasan mengidentifikasi sifat-sifat bangun ruang. C). Observasi dan evaluasi: Pada tahap ini dilakukan observasi terhadap pelaksanaan tindakan dengan menggunakan lembar observasi, dimana pada tahap ini peneliti dan siswa diobservasi oleh guru bidang studi selaku observer tentang pelaksanaan kegiatan belajar mengajar pada pokok bahasan mengidentifikasi sifat-sifat bangun ruang, apakah pembelajaran sudah sesui dengan scenario dan RPP yang telah dibuat. Sedangkan evaluasi dilakukan oleh guru mata pelajaran Matematika yang ada di sekolahnya sendiri dngan memberikan tes subyektif kepada siswa setiap akhir siklus. D). Refleksi: Refleksi dilakukan pada akhir setiap siklus. Pada tahap ini, peneliti mengkaji hasil yang diperoleh dari pemberian tindakan pada siklus I pada pokok bahasan mengidentifikasi sifat-sifat bangun ruang, sebagai acuan dalam refleksi ini digunakan sebagai dasar untuk memperbaiki serta menyempurnakan perencanaan dan pelaksanaan tindakan pada siklus II pada pokok bahasan mengidentifikasi sifat-sifat bangun ruang.

2) Siklus kedua: Siklus II dilakukan apabila pembelajaran pada siklus I dinilai belum berhasil mencapai ketuntasan dan proses belajar mengajar belum sesui dengan apa yang diinginkan, sedangkan langkah-langkah yang dilakukan dalam siklus II pada dasarnya sama dengan langkah-langkah pada siklus I hanya pada siklus II dilakukn tahap kekurangan pada siklus I begitu juga pada siklus berikutnya.

Instrumen penelitian adalah alat atau fasilitas yang digunakan oleh peneliti dalam mengumpulkan data agar pekerjaan lebih mudah dan hasilnya lebih baik, dalam arti lebih cermat, lengkap dan sistematis sehingga lebih mudah diolah. ${ }^{5}$
Adapun instrument yang digunakan oleh penelitian ini adalah: 1). Lembaran observasi, Sebagaiman insrumen kegiatan yang dilakukan oleh guru dan siswa selama proses belajar mengajar berlangsung. Kegiatan tersebut dapat diketahui dengan lembar observasi aktivitas guru dan lembar observasi aktivitas siswa. 2). Tes hasil belajar, Dalam penelitian ini tes hasil belajar yang digunakan adalah soal bentuk pilihan ganda yang diambil dari beberapa buku paket dengan berpedoman pada kurikulum dan disetujui oleh guru bidang studi. Instrument ini disusun guna mengetahui sejauh mana tingkat pemahaman siswa dalam menguasai materi yang telah disampaikan. Adapun instrument yang digunakan untuk mengamati aktivitas dan prestasi belajar siswa dengan menggunakan media tiga dimensi tersebut tertera sebagai berikut:

Sumber data dalam penelitian ini berasal dari peneliti, observer, dan siswa kelas V MIN 2 Lombok Barat: a), Jenis data, b), Jenis data yang didapatkan adalah data kuantitatif dan kualitatif yang terdiri dari: 1), Data hasil belajar (data kuantitatif), b). Data hasil observasi pelaksanaan pembelajaran berupa data aktivitas siswa dan data aktivitas guru (data kualitatif).

Analisis data merupakan proses yang merinci secara formal untuk menentukan tema dan merumuskan hipotesis seperti yang disarankan oleh data-data sebagai usaha untuk memberikan bantuan pada tema dan hipotesis. Untuk mengetahui keaktifan siswa dan guru dalam pembelajaran, maka dilakukan dengan cara menentukan skor maksimal ideal, mean ideal dan standar devisi. Adapun ketentuan data hasil observasi yang berupa skor diolah dengan rumus:

1. Menentukan kemampuan individu

Menentukan skor maksimal ideal (SMi) $=100$

Menentukan mean ideal (M)

$\mathrm{Mi}=\frac{1}{2} \mathrm{x}$ SMI $(100)=50$

Menentukan standar devisi ideal (SDi)

$\mathrm{SDi}=\frac{1}{3} \times \mathrm{Mi}=\frac{1}{3} \times 50=16,67$

Konversi Nilai

Taraf kemampuan tinggi di atas Mi + 1 (SDi).

Taraf kemampuan sedang adalah diantara $\mathrm{Mi}+$ 1(SDi) dan Mi-1(SDi).

Taraf kemampuan rendah adalah dibawah Mi1(SDi). 6

2. Menentukan kemampuan kelompok

Menentukan mean (rata-rata)

Mean $=\frac{\sum F x}{N}$ 
Keterangan: $\sum F x=$ jumlah perkalian frekuensi dengan nilai tengah

$\sum \mathrm{N}=$ jumlah seluruh siswa

$M$ = nilai rata-rata

Menentukan indeks prestasi kelompok (IPK)

$\mathrm{IPK}=\frac{M}{S M i} x 100$

Keterangan : IPK = indeks prestasi kelompok

$\mathrm{M}=$ mean atau nilai rata-rata

SMi = Skor maksimak ideal

$100=$ bilangan tetap ${ }^{7}$

Berikut ini adalah kriteria sebagai pedoman dal am menentukan indeks prestasi kelompok (IPK).

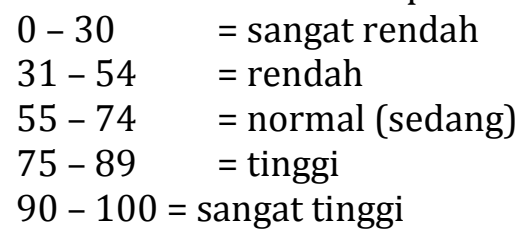

\section{HASIL DAN PEMBAHASAN}

Berdasarkan hasil penelitian penggunaan media tiga dimensi dalam pembelajaran dapat dikemukakan pendapat sebagai berikut.

1. Penggunaan media tiga dimensi dalam meningkatan Hasil Belajar siswa MIN 2 Lombok Barat Tahun Pelajaran 2017/2018

Berdasarkan data hasil tes pada pratindakan yang dilakukan peneliti, diperoleh nilai rata-rata kelas sebesar 59,3 dengan nilai tertinggi 85 dan nilai terendah yaitu 30. Sedangkan siswa yang tuntas belajar atau sudah mencapai KKM yang telah ditetapkan yakni 70 berjumlah 10 siswa atau $41,6 \%$ dan siswa yang belum tuntas belajar berjumlah 14 siswa atau 59,3\%. Hasil tersebut menggambarkan bahwa hasil belajar siswa pada materi bangun ruang masih rendah. Oleh karena itu perlu adanya tindakan yang dilakukan dengan segera untuk meningkatkan hasil belajar tersebut. Peneliti memilih tindakan berupa penggunaan media bangun ruang tiga dimensi untuk meningkatkan hasil belajar siswa. Sesuai dengan pendapat Piaget bahwa anak pada usia sekolah dasar berada pada tahap operasional konkret, Pada tahap ini, anak belum dapat menghadapi halhal yang abstrak (tak berwujud) dengan baik. Anak masih memerlukan bantuan benda-benda konkret untuk memahami konsep-konsep yang abstrak. Melalui kegiatan mengkonstruksi pengetahuannya sendiri berdasarkan pengalaman langsung yang dilakukannya. Dengan begitu pengetahuan yang diperolehnya lebih bermakna dan memberi kesan. ${ }^{8}$

\section{Ibid, 100}

${ }^{8}$ Heruman. Model Pembelajaran Matematika di Sekolah Dasar.
Dalam penelitian ini setiap siklus terdiri dari perencanaan, tindakan, observasi dan refleksi. Pada siklus II tahap-tahap yang dilakukan merupakan perbaikan dari siklus I. Hasil yang diperoleh pada penelitian ini terdiri dari data tes yang berupa hasil belajar siswa serta data non tes yang terdiri dari hasil observasi dan dokumentasi.

Nilai rata-rata kelas pada pembelajaran siklus I menunjukkan peningkatan bila dibandingkan dengan tahap pratindakan, yaitu dari 59,3 menjadi 69,3 . Nilai tertnggi 90 dan nilai terendah 40 . Sementara persentase siswa yang telah mencapai KKM pada siklus I meningkat $10 \%$ dari $59,3 \%$ pada pratindakan menjadi $69,3 \%$ pada siklus I. Sedangkan siswa yang tuntas belajar atau sudah mencapai KKM yang telah ditetapkan yakni 70 berjumlah 16 siswa dan siswa yang belum tuntas belajar berjumlah 8 siswa.

Peningkatan hasil belajar siswa yang terjadi pada siklus I karena dengan adanya penggunaan media yang berupa bangun ruang tiga dimensi. Siswa secara aktif melakukan pengamatan terhadap model-model bangun ruang yang disiapkan guru. Melalui penggunaan model-model bangun ruang, siswa belajar secara lebih konkret dan menemukan sendiri konsep materi tentang sifat-sifat bangun ruang dan jaring-jaring bangun ruang sehingga akan lebih mudah memahami dan mengingat konsep tersebut. Hal ini sesuai dengan pendapat Piaget bahwa dalam belajar siswa harus mengalami sendiri dan terlibat langsung secara realistik dengan objek yang dipelajarinya. Belajar harus bersifat aktif. Sejalan dengan pendapat tersebut, Brunner mengemukakan bahwa dalam belajar siswa berkmunikasi dengan lingkungannya melalui eksplorasi dan manipulasi objek, membuat pertanyaan dan melakukan eksperimen. Menurutnya, untuk memulai belajar konsep dan prinsip siswa harus mengkonstruksi sendiri konsep dan prinsip yang dipelajari itu.

Pada penelitian siklus I persentase keberhasilannya belum mencapai $80 \%$, karena baru mencapai $69 \%$ dari jumlah siswa yang mendapat nilai $>70$. Untuk itu penelitian dilanjutkan ke siklus II dengan melihat catatancatatan penting yang masih perlu direfleksikan lagi untuk pembelajaran berikutnya.

Pelaksanaan tndakan siklus II ini merupakan tindak lanjut dari siklus I. Pada siklus I ditemukan faktor penyebab kurang tercapainya indikator keberhasilan diantaranya siswa masih kurang semangat dan kurang aktif ketika diskusi kelompok, waktu kurang efektif, alat peraga dijadikan mainan, siswa masih takut dan malu untuk mengemukakan pendapatnya, siswa yang 
aktif bertanya dan menyampaikan pendapat masih sedikit, ketika menunggu giliran untuk presentasi siswa malah bercanda dan bermain dengan teman kelompoknya.

Tindakan yang dilakukan pada siklus II masih tahap menggunakan alat peraga yaitu bangun ruang tiga dimensi. Guru juga lebih intensif memeberikan bimbingan pada kelompokkelompok dalam diskusi dan memotivasi siswa agar lebih berani dalam menyampaikan pendapat ketika presentasi. Guru mengintruksikan dengan jelas kepada semua kelompok agar membagi tugas terlebih dahulu sehingga semua siswa bekerja, merasa bertanggung jawab dan waktu tidak terbuang sia-sia. Hal ini sejalan dengan pernyataan Kemp dan Dayton dalam buku Arsyad, bahwa peran guru ketika melakukan pembelajaran menggunakan media tidak lagi terpusat pada penjelasan bahan pelajaran yang berulang-ulang. Guru dapat memusatkan perhatian kepada aspek penting lain dalam proses pembelajaran, misalnya sebagai konsulitan siswa. Peran guru lebih banyak pada motivasi dan mendorong kegiatan siswa serta sebagai pembimbing dan fasilitator bagi siswa dalam proses rekonstruksi ide dan konsep Matematika. ${ }^{9}$

Adanya upaya perbaikan tindakan pada siklus II ini, maka hasil pembelajaran menjadi meningkat jika dibandingkan dengan pratindakan dan siklus I. Hal ini dapat dilihat pada tabel dibawah ini.

Table 12. perbandingan hasil belajar pada pratindakan, siklus I dan siklus II

\begin{tabular}{|l|l|l|l|l|}
\hline No & \multicolumn{1}{|c|}{ Aspek } & Pratindakan & Siklus I & \multicolumn{1}{|c|}{ Siklus II } \\
\hline 1. & Nilai tertinggi & 85 & 90 & 95 \\
\hline 2. & NilaiTerendah & 30 & 40 & 60 \\
\hline 3. & Nilai Rata-rata & 59,3 & 69,3 & 77,5 \\
\hline 4. & $\begin{array}{l}\text { Presntasi } \\
\text { ketuntasan }\end{array}$ & $41,6 \%$ & $66,6 \%$ & $91,6 \%$ \\
\hline
\end{tabular}

Jika nilai rata-ratav yang dicapai siswa pada pratindakan, siklus I, dan siklus II disajikan dengan diagram maka hasilnya adalah sebagai berikut.

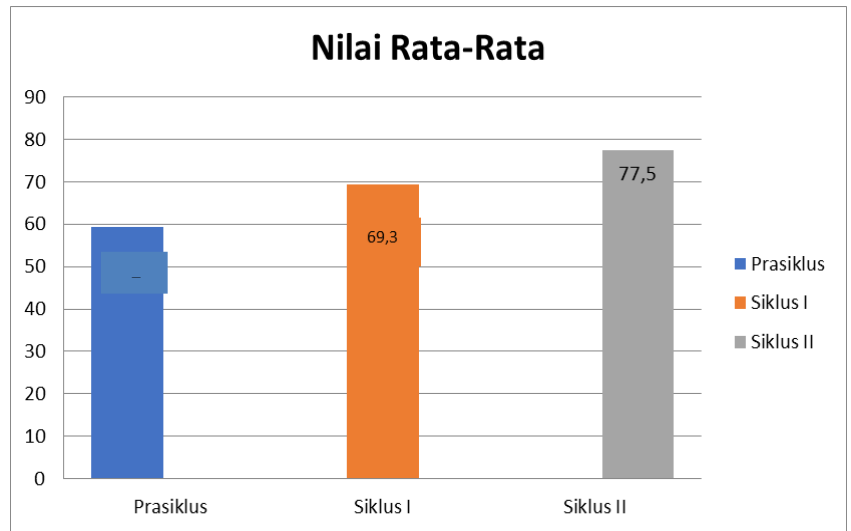

${ }^{9}$ Azhar Arsyad, Media Pembelajaran. (Jakarta: Rajawali Pers, 2011), 21-23
Gambar 2. Diagram Perbandingan Nilai Rata-Rata Siswa pada Pratindakan, Siklus I dan Siklus II

Berdasarkan diagram di atas, nilai rata-rata siswa mengalami peningkatan pada setiap tahapan penelitian. Pada tahap pratindakan nilai rata-rata siswa mencapai 59,3 dan pada siklus I meningkat menjadi 69,3 kemudian meningkat lagi pada siklus II menjadi 77,5. Sedangkan diagram perbandingan persentase ketuntasannya adalah sebagai berikut

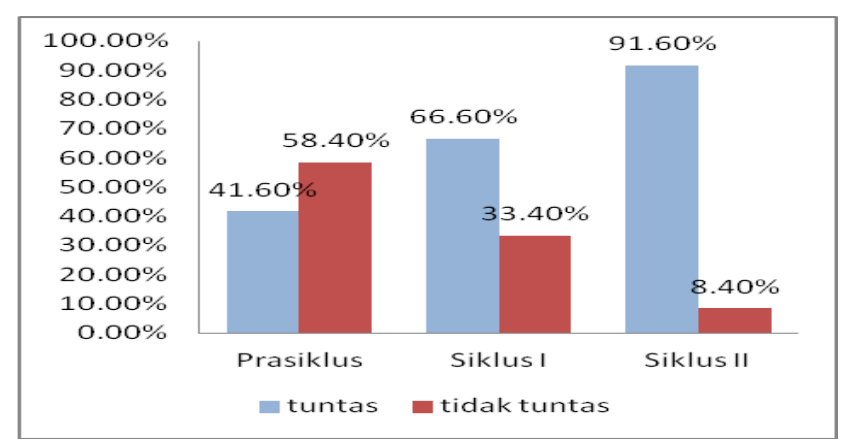

Gambar 3. Diagram Perbandingan Persentase Ketuntasan Siswa pada Pratindakan, Siklus I dan Siklus II

Berdasarkan diagram di atas, persentase siswa yang telah mencapai KKM juga semakin meningkat selama penelitian. Pada tahap pratindakan persentase ketuntasannya baru mencapai $41,6 \%$ sedangkan pada siklus I ketuntasan siswa meningkat menjadi $66,6 \%$ akan tetapi ketuntasan ini belum mencapai kriteria yang ditetapkan yaitu 80\% sehingga dilakukan tindakan siklus II. Pada tindakan siklus II ketuntasan siswa meningkat lagi menjadi $91,6 \%$ artinya sudah mencapai kriteria ketuntasan yang ditetapkan peneliti sehingga penelitian dihentikan. Sedangkan siswa yang tidak tuntas belajar mengalami penurunan disetiap tahapan penelitian. Pada pratindakan siswa yang tidak tuntas belajar mencapai $58,40 \%$ pada siklus I menurun menjadi $34,40 \%$ dan pada siklus II menurun lagi menjadi $8,40 \%$. Selain peningkatan hasil belajar, penggunaan media tiga dimensi juga mampu meningkatkan aktivitas siswa dalam mengikuti proses pembelajaran Matematika materi bangun ruang. Peningkatan aktivitas siswa dilihat dari keantusiasan siswa dalam mengikuti proses pembelajaran, keterlibatan siswa dalam menggunakan media, kerja sama dalam kelompok, keberanian mengemukakan pendapat dan menjawab pertanyaan guru, dan kepatuhan dalam mengikuti aturan yang disepakati. Peningkatan aktivitas siswa dari siklus I ke siklus II dapat dilihat pada diagram beri kut. 


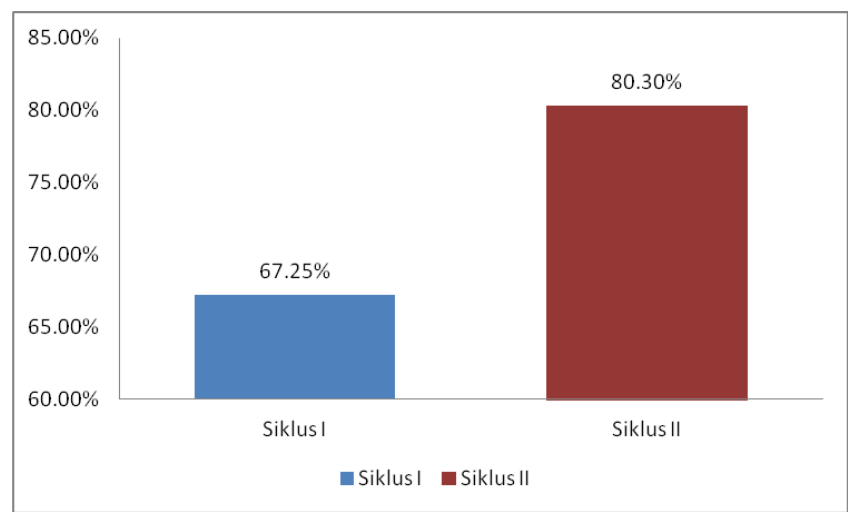

Gambar 4. Diagram Perbandingan Rata-rata Persentase

Berdasarkan diagram di atas, dapat diketahui bahwa rata-rata persentase aktivitas siswa dalam proses pembelajaran bangun ruang menggunakan media tiga dimensi mengalami peningkatan. Pada siklus I rata-rata persentase aktivitas siswa sebesar $67,25 \%$. Pada siklus II meningkat sebesar 13,05\% menjadi 80,30.

Peningkatan hasil belajar dan aktivitas siswa ini bisa terjadi dikarenakan penggunaan media tiga dimensi pada proses pembelajaran bangun ruang. Siswa terlibat aktif dalam mengkonstruksi pengetahuannya melalui bantuan model-model bangun ruang. Selain itu, siswa juga bekerja sama dan bertanggung jawab saat melakukan kegiatan dalam kelompoknya.

Berdasarkan hasil penelitian, Penggunaan media tiga dimensi dalam pembelajaran Matematika tidak ditemukan kendala yang berarti dikarenakan siswa dalam pembelajaran dapat menggunakan dan memanfaatkan media tiga dimensi dengan baik. hanya saja media tiga dimensi tidak mampu menjangkau sasaran dalam jumlah yang banyak dan penyimpanan media memerlukan ruang dan perawatan, ini sesuai dengan pendapat Moedjiono dalam Daryanto. ${ }^{10}$ Karena media pembelajaran tiga dimensi dibuat dari kertas manila yang apabila tidak dilakuakan perawan dan disimpan ditempat yang baik mengakibatkan media cepat rusak dan apabila digunakan kembali media tersebut tidak memiliki ketertaran lagi, sihingga guru harus membuat ulang media tiga dimensi yang baru.

\section{SIMPULAN DAN SARAN}

Berdasarkan hasil penelitian dan pembahasan yang telah dilakukan, maka dapat diambil kesimpulan sebagai berikut.

Penggunaan media tiga dimensi dalam pembelajaran bangun ruang pada siswa kelas $\mathrm{V}$ MIN 2 Lombok Barat dapat meningkatkan hasil belajar siswa. Hal ini dibuktikan dengan peningkatan nilai rata-rata kelas dan persentase ketuntasan siswa pada setiap tahapan penelitian. Pada tahap pratindakan nilai rata-rata siswa mencapai 59,3 dan pada siklus I meningkat menjadi 69,3 kemudian meningkat lagi pada siklus II menjadi 77,5. Sementara persentase ketuntasan siswa pada tahap pratindakan baru mencapai $41,6 \%$ sedangkan pada siklus I ketuntasan siswa meningkat menjadi $66,6 \%$ kemudian meningkat lagi pada siklus II menjadi 91,6\%.

Penggunaan media tiga dimensi dalam pembelajaran bangun ruang pada siswa kelas $\mathrm{V}$ MIN 2 Lombok Barat dapat meningkatkan kualitas proses pembelajaran. Hal ini dibuktikan dengan peningkatan aktivitas siswa selama proses pembelajaran dari siklus I sebesar $67,2 \%$ menjadi $80,3 \%$ pada siklus II dengan kategori baik.

Penggunaan media tiga dimensi dalam pembelajaran tidak ditemukan kendala yang berarti dikarenakan siswa dapat menggunakan media tiga dimensi dengan baik, hanya saja media tiga dimensi tidak mampu menjangkau sasaran dalam jumlah yang banyak dan penyimpanan media memerlukan ruang dan perawatan.

\section{DAFTAR RUJUKAN}

Abdul Halim, F. Matematika (hakikat dan Logika). (Yogyakarta: Ar-ruzz media. 2009).

Andi Prastowo, Menyusun Rencana Pelaksanaan Pembelajran (RPP) Tematik Terpadu,(Jakarta: Kencana, 2015)

Angkowo dan Kosasih. Optimalisasi Media Pembelajaran. (Grasindo. Jakarta. 20011).

Arikunto Suharsimi, metode penelitian kuantitatif, kualitatif, (Bandung: Alfabeta, 2010)

Azhar Arsyad, Media Pembelajaran. (Jakarta: Rajawali Pers, 2011)

Bahrur Rosidi, media pembelajaran, dalam bahrurrosyididuraisy.wordpress.commedia-pembelajaran (diunduh pada tanggal 12 Maret 2018 jam 21.25)

Daryanto, Media Pembelajaran, (Yogyakarta: Gava Media, 2013)

Daryanto, Panduan Proses Pembelajaran, Kreatif \&Inovatif, (Publisher:2009)

Depdiknas, Kurikulum Tingkat Satuan Pendidikan:Standar Isi Mata Pelajaran Matematika, (Jakarta: Depdiknas, 2006)

Heruman. Model pembelajaran Matematika disekolah dasar. (Bandung: PT Remaja Rosadakarya. 2019)

https://www.slideshare.net/NizaZaid/media-tigadimensi-60366590. diunduh pada tanggal 17 maret 2018 
Muhibbin Syah, Psikologi Pendidikan, (Bandung, Remaja Rosdakarya, 2014)

Nana Sujana \& Ahmad Rivai, Media pembelajaran, (Bandung: Sinar Baru Algesindo, 2010)

Nyayu Khodijah, Psikologi Pendidikan, (Jakarta: Rajagrafindo Persada, 2014)

Pentingnya media dalam pembelajaran. http://belajarpsikologi.com/pentingnyamedia-dalam-pembelajaran/, (di unduh pada tanggal 25 februari 2018)

Poewanto, belajar dan Pembelajar, (Jakarta: Rineka Cipta, 2013)

Rayandra Asyhar. Kreatif mengembangkan Media Pembelajaran. (Jakarta: Referensi Jakarta, 2012)

Rostina Sundayana, Media dan Alat Peraga dalam Pembelajaran Matematika, (Bandung: Alfabeta, 2016)

Syahrir. Metodologi Pembelajaran Matematika. (Yogyakarta: Naufan Pustaka. 2010)

Trianto Ibnu Badar, desain penegmbangan pembelajaran tematik bagi anak usia dini \& anak kelas awal $\mathrm{Sd} / \mathrm{Mi}$, implementasi kurikulum 2013, Cet III, (Jakarta: Kencana, 2015) 229-230

Wilkel, Konstruktivisme Berbasis Sekolah, (Malang: Bayumedia Publishing, 2009)

Wina sanjaya, Media Komunikasi Pembelajaran, cet. II, (Jakarta: Kencana, 2014) 